ARTICLE

\title{
Assessing the importance of thermogenic degassing from the Karoo Large lgneous Province (LIP) in driving Toarcian carbon cycle perturbations
}

Thea H. Heimdal (10 ${ }^{1 凶}$, Yves Goddéris (ID ${ }^{2}$, Morgan T. Jones (iD ${ }^{1} \&$ Henrik H. Svensen ${ }^{1}$

The emplacement of the Karoo Large Igneous Province (LIP) occurred synchronously with the Toarcian crisis (ca. $183 \mathrm{Ma}$ ), which is characterized by major carbon cycle perturbations. A marked increase in the atmospheric concentration of $\mathrm{CO}_{2}\left(\mathrm{pCO}_{2}\right)$ attests to significant input of carbon, while negative carbon isotope excursions (CIEs) in marine and terrestrial records suggest the involvement of a ${ }^{12} \mathrm{C}$-enriched source. Here we explore the effects of pulsed carbon release from the Karoo LIP on atmospheric $p \mathrm{CO}_{2}$ and $\delta^{13} \mathrm{C}$ of marine sediments, using the GEOCLIM carbon cycle model. We show that a total of $20,500 \mathrm{Gt} C$ replicates the Toarcian $p \mathrm{CO}_{2}$ and $\delta^{13} \mathrm{C}$ proxy data, and that thermogenic carbon $\left(\delta^{13} \mathrm{C}\right.$ of $-36 \%$ ) represents a plausible source for the observed negative CIEs. Importantly, an extremely isotopically depleted carbon source, such as methane clathrates, is not required in order to replicate the negative CIEs. Although exact values of individual degassing pulses represent estimates, we consider our emission scenario realistic as it incorporates the available geological knowledge of the Karoo LIP and a representative framework for Earth system processes during the Toarcian.

\footnotetext{
${ }^{1}$ Centre for Earth Evolution and Dynamics (CEED), University of Oslo, Oslo, Norway. ${ }^{2}$ Géosciences-Environnement Toulouse, CNRS-Université Paul Sabatier,

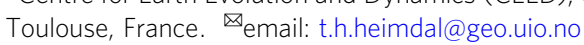


T he Toarcian crisis (ca. 183 Ma) is characterized by extinctions in both the marine and terrestrial realm, localized ocean anoxia (The Toarcian Ocean Anoxic Event; T$\mathrm{OAE}$ ), global warming and major carbon cycle perturbations $\mathrm{s}^{1-15}$. The carbon cycle disturbances are evidenced by increases in the atmospheric concentration of $\mathrm{CO}_{2}\left(\mathrm{CO}_{2}, 1^{1-3}\right)$ and negative carbon isotope excursions (CIEs) recorded in both carbonate and organic matter in marine and terrestrial $\operatorname{archives}^{4-14}$. A prominent negative CIE marks the onset of the T-OAE, and varies in magnitude in both carbonate and organic matter $\left(\delta^{13} \mathrm{C}_{\text {carb }} \approx-0.6\right.$ to $-6.0 \%$; $\delta^{13} \mathrm{C}_{\text {org }} \approx-0.8$ to $-8.6 \%$; see review in ref. ${ }^{15}$ ). High-resolution $\delta^{13} \mathrm{C}$ curves from multiple sections show a stepwise character of the excursion, with several abrupt negative shifts making up the full body of the $\mathrm{CIE}^{3,4,6-9,11,12,14-17}$.

High-precision U-Pb geochronology demonstrates that the Karoo LIP in South Africa and Lesotho (Fig. 1) was emplaced synchronously with the T-OAE negative CIE (Fig. 2; ref. ${ }^{18-21}$ ). This has led to the hypothesis that Karoo-derived emissions were responsible for the carbon cycle perturbations (e.g., $1,7,18-21$,); however, the negative shift in $\delta^{13} \mathrm{C}$ is of such magnitude that mantle-derived carbon alone is unlikely to have been the source $^{22}$. Alternative suggestions include marine methane clathrate dissociation (e.g., $, 8,22$,), permafrost melting ${ }^{23}$, terrestrial organic matter ${ }^{24,25}$, or thermogenic carbon release generated by sill emplacement into organic-rich sedimentary rocks of the Karoo Basin (e.g., $1,19,22,26$,).

Volcanic basins, such as the Karoo, are characterized by a pulsed emplacement of sills (e.g. ${ }^{27}$, ), leading to pulsed contact metamorphism and fluid release. Notably, a stepwise decrease in $\delta^{13} \mathrm{C}$ is suggestive of isotopically light carbon supplied in pulses to the ocean-atmosphere system ${ }^{28}$. Field investigations, borehole studies, and numerical modeling suggest thermogenic carbon generation on the order of several thousand gigatons within the Karoo basin $26,29-31$. The presence of thousands of explosion pipes and hydrothermal vent complexes rooted in the contact metamorphic aureoles represent a plausible release mechanism, and attests to rapid emissions of the thermogenic gases $^{26,32}$. Available high-precision $\mathrm{U}-\mathrm{Pb}$ ages of the sills and thermogenic emission estimates from the Karoo Basin allows to identify detailed and realistic emission scenarios from the Karoo LIP; however, these have not yet been tested by carbon cycle modeling.

Here, we test such scenarios using the GEOCLIM model ${ }^{33,34}$, in order to explore whether pulsed carbon release from the Karoo LIP could explain the full extent of observed Toarcian $p \mathrm{CO}_{2}$ and $\delta^{13} \mathrm{C}$ changes. The emission scenarios are grounded by $\mathrm{U}-\mathrm{Pb}$ geochronology, detailed evolution of the Karoo LIP, and estimates of both the mantle-derived and thermogenic carbon from volcanic and contact metamorphic degassing, respectively.

\section{Results}

In order to investigate the consequences of carbon release from the Karoo LIP, it is essential to constrain the timing between the negative CIEs, $p \mathrm{CO}_{2}$ excursion, and Karoo activity. Following the correlations used here (see Supplementary Note $1 ; 18,19,35)$, the T-OAE lasted for $500 \mathrm{kyr}$, and overlaps with the full extent of the carbon isotope perturbations (Fig. 2). This corresponds to the onset of the negative CIEs, as well as peak negative values, and the subsequent interval of $\delta^{13} \mathrm{C}$ increase eventually reaching background levels. Reconstructed $p \mathrm{CO}_{2}$ curves from the Danish Basin show an increase in $p \mathrm{CO}_{2}$ of up to $\sim 2000 \mathrm{ppm}$ during the T-OAE (including uncertainties; ref. ${ }^{1}$ ). Following our correlations, the $p \mathrm{CO}_{2}$ peak coincides with the peak negative $\delta^{13} \mathrm{C}$ values (Fig. 2). The $p \mathrm{CO}_{2}$ records do not include absolute time constraints, so the correlation of $p \mathrm{CO}_{2}$ data with the Karoo activity and various carbon isotope records was based on the extent of the T-OAE (see Supplementary Note 1). Available U-Pb ages of Karoo intrusives demonstrate that the Karoo igneous activity overlaps with the full extent of the Toarcian CIEs and by inference the $p \mathrm{CO}_{2}$ peak (Fig. 2; ref. ${ }^{18-21}$ ).

The Karoo intrusives postdate a $\sim 1-2 \%$ negative CIE that occurs around the Pliensbachian-Toarcian (Pl-T) boundary in some sections (e.g. ${ }^{5,36}$, Fig. 2), excluding a temporal link between Karoo igneous activity and this earlier disruption of the carbon cycle ${ }^{37}$. As this CIE is not systematically recorded, and there is no evidence for $p \mathrm{CO}_{2}$ increase or Karoo activity at this time, it is not considered in this study. Furthermore, we stress that there are alternative correlations and interpretations for the Toarcian carbon cycle perturbations that differ from those used here, particularly with respect to the duration of the full extent of the T-OAE CIE, which varies from 120 to 2400 kyr (Supplementary Note $1 ; 4,7,8,18,19,35,38-43$ ).

The total model run is set to $500 \mathrm{kyr}$, which corresponds to the total duration of the T-OAE (following the correlations used here; Fig. 2; Supplementary Note 1). Both volcanic and thermogenic processes associated with the Karoo LIP activity are accounted for in the emission scenario. Seven thermogenic carbon pulses $\left(\delta^{13} \mathrm{C}\right.$ of $-36 \%$; Supplementary Note 1) are released between model time $(t)=30$ and $262 \mathrm{kyr}$ (pulses \#2-8; Table 1; Supplementary Fig. 1), which is constrained by the timing of negative CIEs. The thermogenic carbon pulses vary in magnitude, between 300 and $3800 \mathrm{Gt}$. The total magnitude of released mantle-derived carbon (with $\delta^{13} \mathrm{C}$ of $-5 \%$ ) is set to $8000 \mathrm{Gt}$, following average estimates for the Karoo LIP (e.g., ref. ${ }^{22}$; Supplementary Note 1). $4500 \mathrm{Gt}$ mantle-derived carbon is released at $t=160$ (pulse \#6; Table 1), while the remaining $3500 \mathrm{Gt} \mathrm{C}$ is released as a long-lasting and continuous pulse between $t=0$ and $262 \mathrm{kyr}$ (pulse \#1; Table 1; Supplementary Fig. 1; Supplementary Note 1). Note that carbon pulse \#6 represents a mix of both mantle-derived and thermogenic carbon, with a total magnitude of $7000 \mathrm{Gt}$ and a $\delta^{13} \mathrm{C}$ value of $-16 \%$ (Table 1; Supplementary Note 1). Except for the continuous mantle-derived carbon pulse (pulse \#1), the carbon releases have durations of 3-22 kyr, which is constrained by the duration of observed carbon cycle perturbations targeted, and in agreement with modeling studies suggesting that the generation of thermogenic fluids occurs on timescales of 100 's to $1000^{\prime}$ 's years ${ }^{29,44}$.

The pulsed release of a total of $20,500 \mathrm{Gt} C$ leads to a stepwise increase in $p \mathrm{CO}_{2}$ from $\sim 650 \mathrm{ppm}$ up to a maximum of $\sim 1700$ $\mathrm{ppm}$. The modeled $p \mathrm{CO}_{2}$ curve plots generally within the range of observed data, with the exception of the fourth peak (at $t=111 \mathrm{kyr}$ ), which overestimates the $p \mathrm{CO}_{2}$ (Fig. 3). The modeled $\delta^{13} \mathrm{C}_{\text {carb }}$ curve decreases in seven steps (between $\sim 0.3$ and $\sim 1.8 \%$ ), with a total negative shift $\left(\delta^{13} \mathrm{C}_{\max }-\delta^{13} \mathrm{C}_{\text {preT-OAE }}\right)$ of $\sim$ $-4 \%$. Following the $\delta^{13} \mathrm{C}_{\text {carb }}$ data, the modeled $\delta^{13} \mathrm{C}_{\text {org }}$ curve also decreases in seven steps (between $\sim 0.5$ and $\sim 3.7 \%$ ), but with larger magnitudes, as well as a larger a total negative shift of $\sim-6 \%$. Both the modeled $\delta^{13} \mathrm{C}_{\text {carb }}$ and $\delta^{13} \mathrm{C}_{\text {org }}$ curves generally plot within the range of observed data considering both the magnitude and shape of the negative shift (Fig. 3). There are however some exceptions: 1$)$ the modeled $\delta^{13} \mathrm{C}_{\text {carb }}$ curve predicts slightly lower $\delta^{13} \mathrm{C}$ values at the end of the model run during the recovery interval of $\delta^{13} \mathrm{C}$ increase, and 2) the modeled $\delta^{13} \mathrm{C}_{\text {org }}$ curve does not replicate all of the shortlived negative CIEs making up the prolonged interval of negative $\delta^{13} \mathrm{C}$ values following peak negative values. Note that all observed $\delta^{13} \mathrm{C}$ curves are from shallow marine stratigraphic sections, and is accordingly compared to model $\delta^{13} \mathrm{C}$ data representing a shallow ocean epicontinental sea or shelf environment (i.e., epicontinental surface reservoir boxes; see Methods). 

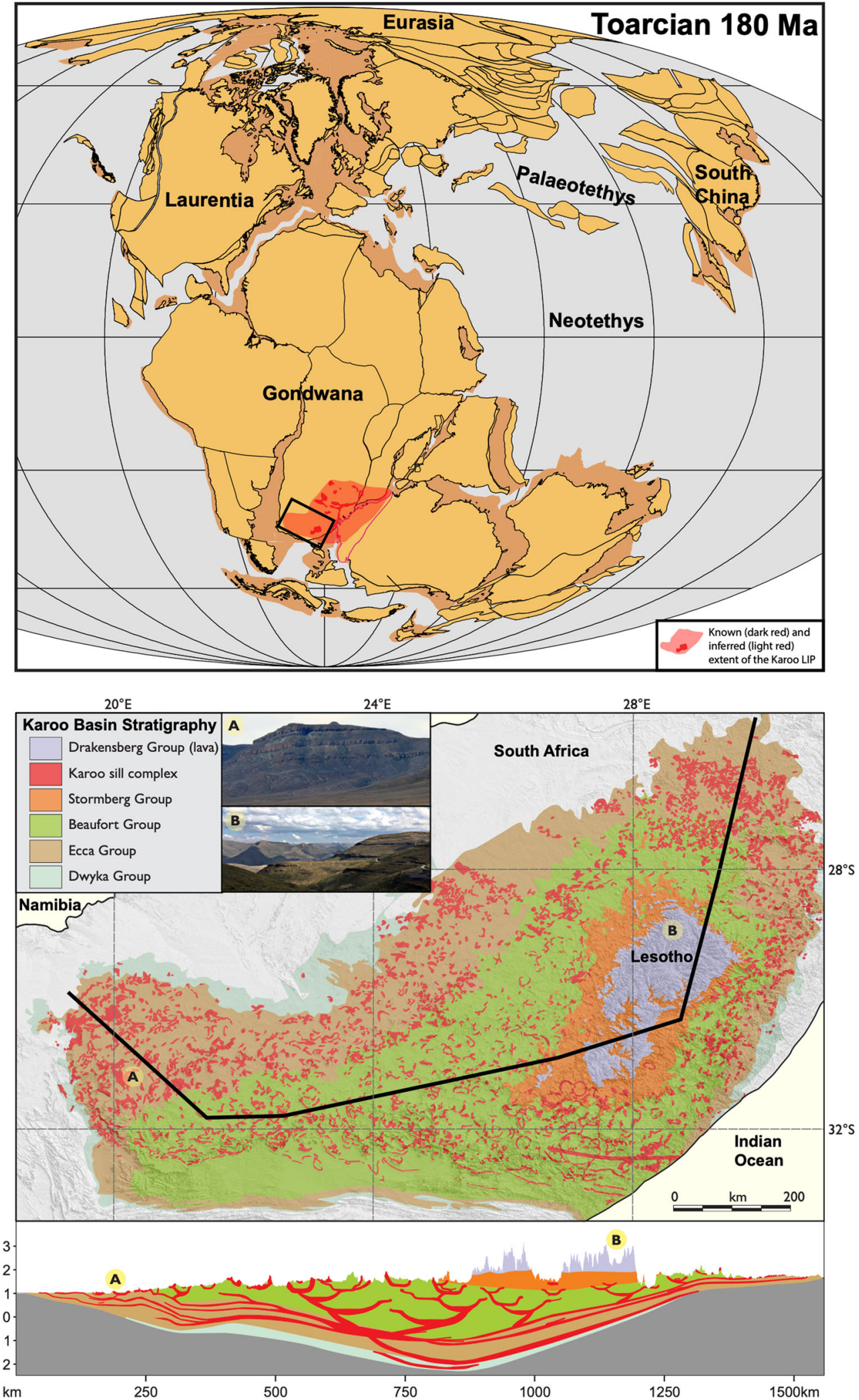

Fig. 1 Location and cross section of the Karoo Basin. Top: a plate reconstruction at $180 \mathrm{Ma}$ (modified from ref. 60; Fig. 12.2) showing the known and inferred extent of the Karoo Large Igneous Province (LIP) ${ }^{21,61}$. Bottom: a detailed map of the Karoo Basin stratigraphy in South Africa and Lesotho, with a schematic cross section across the province (modified from ref. ${ }^{47}$ ). Photo A shows deep laminar sills of the Ecca Group in western South Africa, while photo B shows the continental flood basalt lavas exposed in Lesotho (positions are labelled as A and B on the map and cross section). 


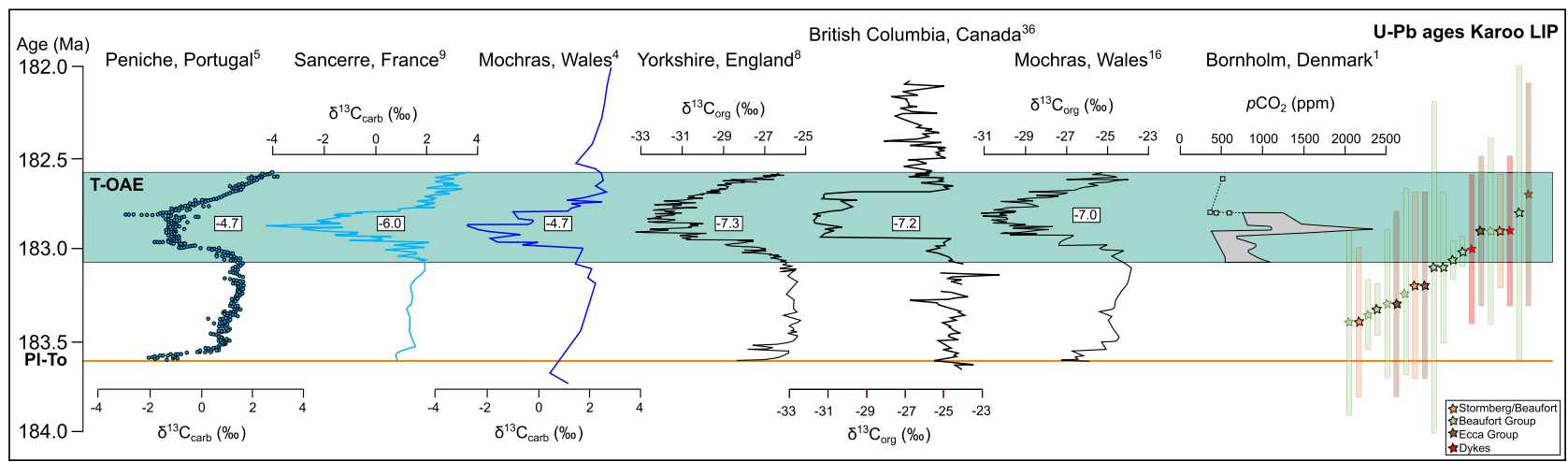

Fig. 2 Correlation between Toarcian carbon cycle perturbations and the timing of Karoo intrusions. Timeline of Karoo activity, the Toarcian Ocean Anoxic Event (T-OAE; green box), carbon isotope curves from shallow marine stratigraphic sections and $p \mathrm{CO}_{2}$ data (including uncertainties) after ref. ${ }^{18,19,35}$. The age of the Pliensbachian-Toarcian (PI-To) boundary (orange line) is from ref. ${ }^{19}$. U-Pb ages of Karoo intrusives are from ref. ${ }^{18-21}$. U-Pb color codes refer to sill emplacement levels in the Karoo Basin, and corresponds to the colors used in the map and cross section in Fig. 1. Numbers in boxes represent the total negative shift $\left(\delta^{13} C_{\max }-\delta^{13} C_{\text {preT-OAE }}\right)$ in $\delta^{13} C_{\text {org }}$ and $\delta^{13} C_{\text {carb }}$.

Table 1 Overview and input values for Karoo emission scenario.

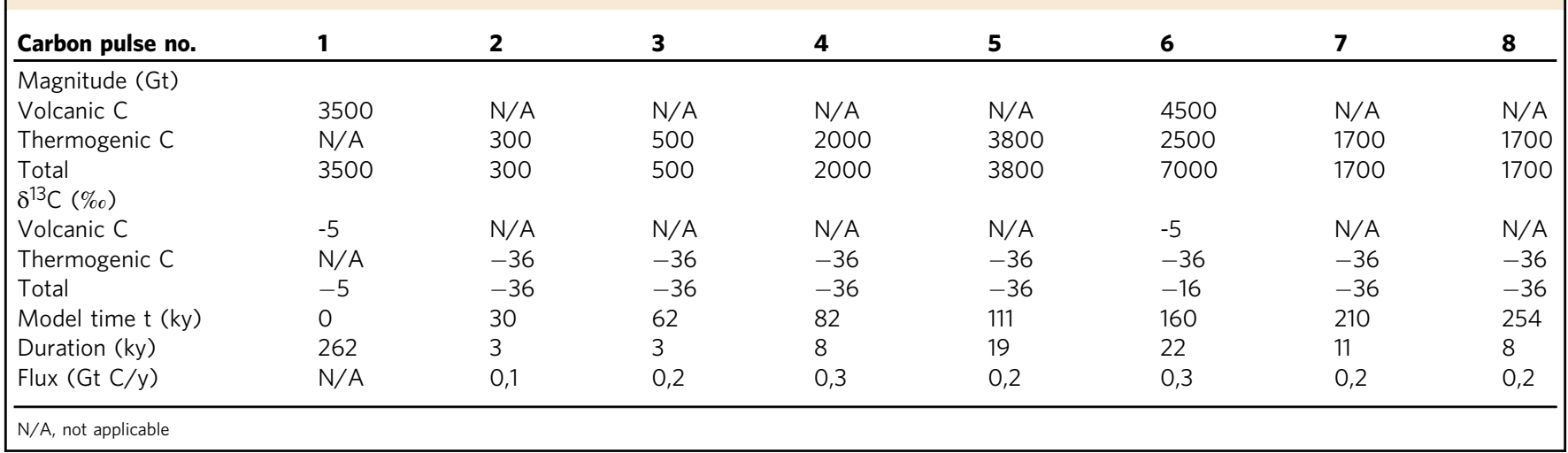

\section{Discussion}

The emission scenario presented here replicates an overall global trend in $\delta^{13} \mathrm{C}$, including several negative steps, and a total negative shift $\left(\delta^{13} \mathrm{C}_{\max }-\delta^{13} \mathrm{C}_{\text {preT-OAE}}\right)$ of $\sim-4 \%$ for $\delta^{13} \mathrm{C}_{\text {carb }}$ and $\sim-6 \%$ o for $\delta^{13} \mathrm{C}_{\text {org. }}$. This is comparable to observed Toarcian carbonate $\delta^{13} \mathrm{C}$ records showing generally lower CIE magnitudes compared to those of organic matter, with mean total CIE values of $\sim-3$ vs. $\sim-5 \%$, respectively ${ }^{15}$. Globally, the total magnitude of the T-OAE CIE ranges considerably (up to $\sim-6$ for $\delta^{13} \mathrm{C}_{\text {carb }}$ and $\sim-9 \%$ o for $\delta^{13} \mathrm{C}_{\text {org }}$; ref. ${ }^{15}$ ), however, the largest excursions are likely exaggerated due to local effects ${ }^{15,43}$. Furthermore, all highresolution Toarcian carbon isotope curves show a stepwise character of the T-OAE excursion, and a series of at least five prominent negative shifts is recognized in numerous carbonate and organic matter Toarcian sections (e.g., Kaszewy, Mochras, Yorkshire, Peniche and Luxembourg; $\left.{ }^{12,45}\right) . \delta^{13} \mathrm{C}$ curves showing one main long-lived T-OAE CIE, or a limited number of negative shifts, have likely failed to record the full extent of the stepped descent due to low sample or stratigraphic resolution. We chose not to take the observed prolonged interval of negative $\delta^{13} \mathrm{C}_{\text {org }}$ values following peak negative values into account, because it is uncertain whether or not this represents a global trend. It has been suggested that, due to improved preservation of marine organic matter under oxygen-depleted conditions, artificial Toarcian $\delta^{13} \mathrm{C}_{\text {org }}$ excursions have been produced ${ }^{40}$. This could potentially explain why there is an apparent prolonged interval of $\delta^{13} C_{\text {org }}$ CIEs, while $\delta^{13} C_{\text {carb }}$ values instead return to background levels (which is also consistent with the shape of the $p \mathrm{CO}_{2}$ curve). Although Toarcian $\delta^{13} \mathrm{C}$ curves vary with respect to the magnitude, number, timing, and durations of the negative CIEs, we consider our modeled $\delta^{13} \mathrm{C}_{\text {carb }}$ and $\delta^{13} \mathrm{C}_{\text {org }}$ curves to be representative for the overall global trend of Toarcian carbon cycle changes.

While the modeled $\delta^{13} \mathrm{C}$ data is compared to several observed $\delta^{13} \mathrm{C}$ curves, available reconstructed Toarcian $p \mathrm{CO}_{2}$ curves are scarce. As seen in Fig. 3, the modeled $p \mathrm{CO}_{2}$ curve generally plots within the range of observed Toarcian $p \mathrm{CO}_{2}$ data from ref. ${ }^{1}$, but potential target $p \mathrm{CO}_{2}$ values represent quite a wide range due to data points with large error bars. Consequently, the magnitude of released carbon could vary greatly and still replicate the observed $p \mathrm{CO}_{2}$ data within the range of uncertainties. However, by respecting both observed $\mathrm{pCO}_{2}$ and $\delta^{13} \mathrm{C}$ curves simultaneously, the possible magnitude of carbon release is narrowed down considerably. Furthermore, based on Toarcian seawater $\mathrm{pH}$ (ref. ${ }^{2}$ ) and $\triangle 13 \mathrm{C}$ data $\left(\delta^{13} \mathrm{C}_{\text {terrigenic }}-\delta^{13} \mathrm{C}_{\text {marine }}\right.$; ref. $\left.{ }^{3}\right)$, a $p \mathrm{CO}_{2}$ increase from $\sim 800-850$ ppm to $\sim 1750-1800 \mathrm{ppm}$ has been calculated (when assuming a release of thermogenic carbon with $\delta^{13} \mathrm{C}$ of -40 to $-30 \%$ or the latter; ref. ${ }^{3}$ ). As seen in Fig. 3, an increase of this magnitude (i.e., $800-850$ to $1750-1800 \mathrm{ppm}$ ) is in very close agreement with the modeled $p \mathrm{CO}_{2}$ data. The overestimation of $p \mathrm{CO}_{2}$ at $t=111 \mathrm{kyr}$ shown by the modeled curve (Fig. 3 ) is likely the result of the low sample resolution of the observed data, as it is very unlikely that a shift in $\delta^{13} \mathrm{C}$ of up to $4 \%$ is not reflected by a change in $p \mathrm{CO}_{2}$. Therefore, we consider the modeled $p \mathrm{CO}_{2}$ curve presented here to 

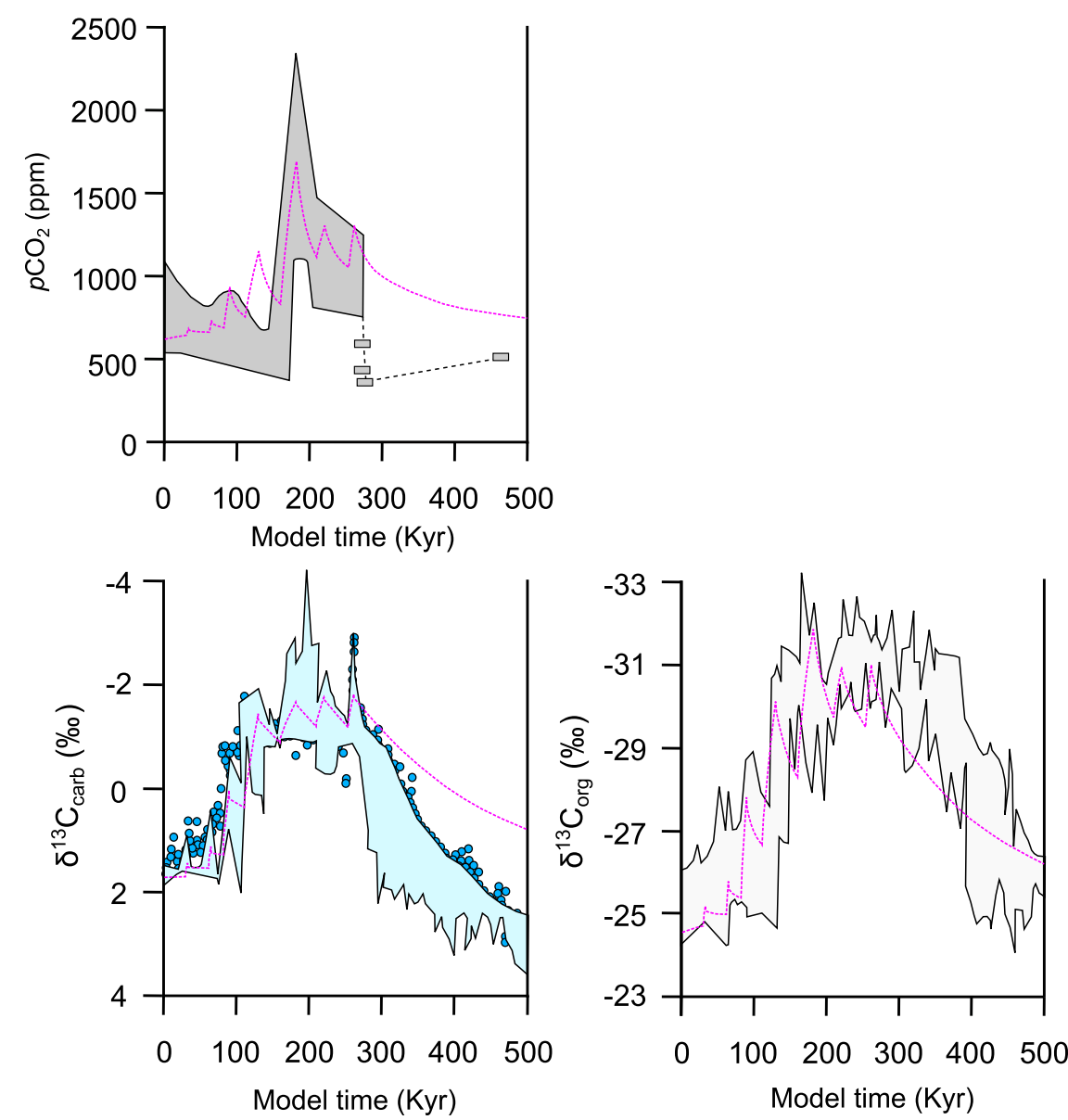

Fig. 3 Modeled $p \mathbf{C O}_{2}$ and $\delta^{13} \mathbf{C}$ curves compared to observed Toarcian data. Model response (pink dashed lines) of $\delta^{13} C_{\text {org }}$ and $\delta^{13} C_{\text {carb }}$ of the shallow ocean (GEOCLIM epicontinental surface reservoir boxes) and atmospheric $p \mathrm{CO}_{2}$ to a Karoo emission scenario including eight pulses of carbon release (see Table 1; Supplementary Fig. 1). Gray and blue outlines represent the range of observed Toarcian $\delta^{13} \mathrm{C}_{\text {carb }}{ }^{4,5,9}, \delta^{13} \mathrm{C}_{\text {org }} 8,16,36$, and $p \mathrm{CO}_{2}$ data ${ }^{1}$, which corresponds to the curves presented in Fig. 2.

be realistic as it reflects Toarcian $p \mathrm{CO}_{2}$ estimates constrained by several methods.

According to our emission scenario, a total release of $20,500 \mathrm{Gt}$ carbon replicates the observed Toarcian $p \mathrm{CO}_{2}$ and $\delta^{13} \mathrm{C}$ data. This number includes $12,500 \mathrm{Gt}$ thermogenic carbon, which is within the range of thermogenic carbon generation estimations from the Karoo Basin ( 7500-23,000 Gt C; ref. $\left.{ }^{26,29-31}\right)$. The ratio of trapped versus released thermogenic gases from volcanic basins is poorly constrained, although $100 \%$ degassing from intrusive LIP components is considered unrealistic (e.g., ${ }^{46}$,). Consequently, the magnitude of released carbon must be lower than the magnitude of carbon generated. The lowermost thermogenic carbon generation estimates are lower than the release value constrained by our modeling. However, these numbers are likely significantly underestimated as they have been upscaled based on a much smaller area of affected host rock compared to that of ref. ${ }^{31}$, and do not include devolatilization of Ecca coals or Beaufort, Dwyka and Stormberg organic-bearing rocks in the Karoo strata (see Fig. 1). According to ref. 31 , an estimated $72 \%$ of the generated carbon gases in the Karoo Basin were released, which corresponds to $\sim 17,000 \mathrm{Gt} \mathrm{C}$. We therefore consider $12,500 \mathrm{Gt}$ to represent a realistic value of cumulative thermogenic carbon release from the Karoo Basin.

Considering the TOC content and sill distribution in the Karoo Basin, sill emplacement into Ecca and Beaufort shales volatilized significantly more carbon-bearing gases compared to sill emplacement at other stratigraphic levels. Within the Ecca and Beaufort series, sills are abundant and can be traced almost continuously with depth, as well as between the basin margins (Fig. 1; ref. ${ }^{47}$ ). In contrast, sills are rare in the Stormberg Group, while devolatilization of Dwyka sedimentary rocks was likely restricted to the upper parts of the series based on the distribution of the sills. The Ecca shales have the highest TOC contents, reaching locally as much as $18 \mathrm{wt} . \%$, while maximum values within the Stormberg, Beaufort and Dwyka Group sedimentary rocks range from 3 to 6 wt. $\%{ }^{48-53}$. Although the TOC contents are overall lower compared to the Ecca Group, the presence of closely spaced large sills (up to $270 \mathrm{~m}$ thick; ref. ${ }^{47}$ ) in the Beaufort Group with TOC up to $\sim 6$ wt. $\%{ }^{52}$ suggests significant gas generation potential at these stratigraphic levels as well. Sill thicknesses and vertical spacing are important factors influencing the gas generation potential; gas generation can increase by up to $\sim 35 \%$ for more closely spaced sills, compared to separate sills emplaced into the same host-rock ${ }^{27}$.

According to our emission scenario, the magnitudes of the individual thermogenic carbon pulses vary throughout the model run (Table 1), which is constrained by the magnitudes of the observed carbon cycle perturbations targeted. The available U-Pb data cannot be used to directly assess the magnitude of the individual degassing pulses as 1) there is no systematic correlation of sill age with stratigraphic emplacement level, and 2) they lack the sufficient resolution (large error bars) to match that of the stepped $\delta^{13} \mathrm{C}$ curves. Importantly, however, the U-Pb geochronology links sill emplacements within organic-rich sedimentary rocks (i.e., Ecca and Beaufort) to the entire interval of Toarcian carbon cycle 
perturbations (Fig. 2). Furthermore, the proposed carbon emission fluxes of 0.2 to $0.3 \mathrm{Gt} \mathrm{C} \mathrm{yr}^{-1}$ (Table 1) corresponds to those estimated for other LIPs (e.g., NAIP and CAMP; 0.1-0.5 Gt $\mathrm{C} \mathrm{yr}^{-1}$; ref. $\left.{ }^{54,55}\right)$. We therefore consider the magnitudes of the individual pulsed thermogenic carbon releases to represent realistic values.

Realistic temporal and volumetric estimates of Karoo LIP volatile emissions can explain the carbon cycle perturbations observed in the Toarcian. Pulsed sill intrusions and contact metamorphism of organic matter-bearing sedimentary rocks in the Karoo Basin represents a significant source of ${ }^{13} \mathrm{C}$-depleted carbon, which can explain the observed negative CIEs. As the lowest $\delta^{13} \mathrm{C}$ value of the released thermogenic carbon in our model is $-36 \%$, an extremely isotopically depleted carbon source (e.g., methane clathrates; $-60 \%$; ref. ${ }^{22}$ ) is not a required component (see also Supplementary Fig. 2). High-precision U-Pb geochronology links sill emplacements within the organic-rich strata of the Karoo Basin to the negative CIEs and the abrupt $p \mathrm{CO}_{2}$ peak. Although the exact values for the different degassing pulses represent estimates, we consider our emission scenario realistic as it incorporates the available geological knowledge of the Karoo LIP and a representative framework for Earth system processes during the Toarcian.

\section{Methods \\ Model description. GEOCLIM couples the 10-box model COMBINE ${ }^{56}$, describing different geochemical cycles (e.g., C, $\mathrm{P}, \mathrm{O}_{2}$, alkalinity, $\mathrm{Sr}$ ) and their associated isotopic cycles $\left(\delta^{13} \mathrm{C},{ }^{87} \mathrm{Sr} /{ }^{86} \mathrm{Sr}\right)$, to the 3D FOAM general circulation climate mode ${ }^{57}$. COMBINE consists of one atmospheric box and nine ocean boxes, including 1) an epicontinental surface reservoir divided in two boxes (surface box up to $100 \mathrm{~m}$ depth; deep box from 100 to $200 \mathrm{~m}$ depth), 2) three mid-latitude ocean boxes (surface, thermocline, and deep), and 3) two polar oceans both divided in two boxes (surface and deep). A full description of the GEOCLIM model can be found in refs. ${ }^{34}$ and ${ }^{56}$. \\ Boundary conditions for the simulations presented here include a Jurassic (180 Ma) paleogeography, which is derived from a synthesis of paleomagnetic data, hot spot tracks and geological constraints ${ }^{34,58}$. The background volcanic degassing rate was set to $4 \times 10^{12} \mathrm{~mol} / \mathrm{yr}$ so that the $p \mathrm{CO}_{2}$ equals $\sim 650 \mathrm{ppm}$ at $\mathrm{t}=0$ (prior to any Karoo degassing), which represents an average value of observed $p \mathrm{CO}_{2}$ data (including uncertainties; ref. ${ }^{1}$ ). \\ GEOCLIM calculates the $\delta^{13} \mathrm{C}$ of the various carbon species (e.g., $\mathrm{H}_{2} \mathrm{CO}_{3}$, POC; particulate organic carbon) in each reservoir/box (e.g., epicontinental surface box). The isotopic fractionation between $\mathrm{H}_{2} \mathrm{CO}_{3} *\left(\mathrm{H}_{2} \mathrm{CO}_{3}+\mathrm{CO}_{2}\right.$; Supplementary Note 1) and POC is set to depend on the calculated $\mathrm{H}_{2} \mathrm{CO}_{3}{ }^{*}$ concentration at each timestep for each oceanic reservoir. As shown in Supplementary Fig. 3a, the fractionation between $\mathrm{H}_{2} \mathrm{CO}_{3}{ }^{*}$ and the POC increases during the interval of carbon injections, but then decreases towards "background values". A decrease in fractionation reduces the difference between the $\delta^{13} \mathrm{C}$ of carbonate and POC, which allows the $\delta^{13} \mathrm{C}_{\text {org }}$ to increase faster compared to $\delta^{13} \mathrm{C}_{\text {carb }}{ }^{59}$. This could potentially explain the apparent decoupling between the $\delta^{13} \mathrm{C}_{\text {org }}$ and $\delta^{13} \mathrm{C}_{\text {carb }}$ modeled curves (Fig. 3; Supplementary Fig. 3b); while the modeled $\delta^{13} \mathrm{C}_{\text {org }}$ curve recovers faster and reach observed values during the recovery interval at the end of the model run, the modeled $\delta^{13} \mathrm{C}$ carb curve predicts slightly lower $\delta^{13} \mathrm{C}$ values compared to observed values.}

\section{Data availability}

All data used for this paper is available in the main text and in the Supplementary Information (Supplementary Note 1, Supplementary Figs. 1-3 and Supplementary References).

\section{Code availability}

The GEOCLIM source code is available upon request to the first author.

Received: 7 April 2021; Accepted: 24 September 2021; Published online: 28 October 2021

\section{References}

1. McElwain, J. C., Wade-Murphy, J. \& Hesselbo, S. P. Changes in carbon dioxide during an oceanic anoxic event linked to intrusion into Gondwana coals. Nature 435, 479-482 (2005).

2. Müller, T. et al. Ocean acidification during the early Toarcian extinction event: Evidence from boron isotopes in brachiopods. Geology 48, 1184-1188 (2020).

3. Rubesam, W., Rolid, M. \& Schwark, L. $\delta 13 \mathrm{C}$ of terrestrial vegetation records Toarcian CO2 and climate gradients. Sci. Rep. 10, 117 (2020).
4. Hesselbo, S. P. et al. Massive dissociation of gas hydrate during a Jurassic oceanic anoxic event. Nature 406, 392-395 (2000).

5. Hesselbo, S. P., Jenkyns, H., Duarte, L. \& Oliveira, L. C. Carbon-isotope record of the Early Jurassic (Toarcian) Oceanic Anoxic Event from fossil wood and marine carbonate (Lusitanian Basin, Portugal). Earth Planet. Sci. Lett. 253, 455-470 (2007).

6. Cohen, A. S., Coe, A. L., Harding, S. M. \& Schwark, L. Osmium isotope evidence for the regulation of atmospheric $\mathrm{CO} 2$ by continental weathering. Geology 32, 157-160 (2004).

7. Cohen, A. S., Coe, A. L. \& Kemp, D. B. The Late Palaeocene-Early Eocene and Toarcian (Early Jurassic) carbon isotope excursions: a comparison of their time scales, associated environmental changes, causes and consequences. $J$. Geol. Soc. 164, 1093-1108 (2007).

8. Kemp, D. B., Coe, A. L., Cohen, A. S. \& Schwark, L. Astronomical pacing of methane release in the Early Jurassic period. Nature 437, 396-399 (2005).

9. Hermoso, M., Callonnec, L. L., Minoletti, F., Renard, M. \& Hesselbo, S. P. Expression of the Early Toarcian negative carbon-isotope excursion in separated carbonate microfractions (Jurassic, Paris Basin). Earth Planet. Sci. Lett. 277, 194-203 (2009)

10. Hermoso, M. et al. Dynamics of a stepped carbon-isotope excursion: ultra high-resolution study of Early Toarcian environmental change. Earth Planet. Sci. Lett. 319-320, 45-54 (2012).

11. Sabatino, N. et al. Carbon-isotope records of the Early Jurassic (Toarcian) oceanic anoxic event from the Valdorbia (Umbria-Marche Apennines) and Monte Mangart (Ju- lian Alps) sections: palaeoceanographic and stratigraphic implications. Sedimentology 56, 1307-1328 (2009).

12. Hesselbo, S. P. \& Pieńkowski, G. Stepwise atmospheric carbon-isotope excursion during the Toarcian Oceanic Anoxic Event (Early Jurassic, Polish Basin). Earth Planet. Sci. Lett. 301, 365-372 (2011).

13. Léonide, $\mathrm{P}$. et al. Drowning of a carbonate platform as a precursor stage of the Early Toarcian global anoxic event (Southern Province sub-Basin, South-east France). Sedimentology 59, 156-184 (2012).

14. Pittet, B., Suan, G., Lenoir, F., Duarte, L. V. \& Mattioli, E. Carbon isotope evidence for sedimentary discontinuities in the lower Toarcian of the Lusitanian Basin (Portugal): sea level change at the onset of the Oceanic Anoxic Event. Sediment. Geol. 303, 1-14 (2014).

15. Remírez, M. N. \& Algeo, T. J. Carbon-cycle changes during the Toarcian (Early Jurassic) and implications for regional versus global drivers of the Toarcian oceanic anoxic event. Earth Sci. Rev. 209, 103283 (2020).

16. $\mathrm{Xu}, \mathrm{W}$. et al. Evolution of the Toarcian (Early Jurassic) carbon-cycle and global climatic controls on local sedimentary processes (Cardigan Bay Basin, UK). Earth Planet. Sci. Lett. 484, 396-411 (2018).

17. Fantasia, A. et al. Global versus local processes during the PliensbachianToarcian transition at the Peniche GSSP, Portugal: a multi-proxy record. Earth-Sci. Rev. 198, 102932 (2019).

18. Sell, B. et al. Evaluating the temporal link between the Karoo LIP and climatic-biologic events of the Toarcian Stage with high-precision U-Pb geochronology. Earth Planet. Sci. Lett. 408, 48-56 (2014).

19. Burgess, S. D., Bowring, S. A., Fleming, T. H. \& Elliot, D. H. High-precision geochronology links the Ferrar large igneous province with early-Jurassic ocean anoxia and biotic crisis. Earth Planet. Sci. Lett. 415, 90-99 (2015)

20. Corfu, F., Svensen, H. \& Mazzini, A. Comment to paper: Evaluating the temporal link between the Karoo LIP and climatic-biologic events of the Toarcian Stage with high-precision U-Pb geochronology by Bryan Sell. Earth Plantetary Sci. Lett. 434, 349-352 (2016). Maria Ovtcharova, Jean Guex, Annachiara Bartolini, Fred Jourdan, Jorge E. Spangenberg, Jean-Claude Vicente, Urs Schaltegger in Earth and Plantetary Science Letters 408 (2014) 48-56.

21. Greber, N. D., et al. New high precision U-Pb ages and Hf isotope data from the Karoo large igneous province; implications for pulsed magmatism and early Toarcian environmental perturbations. Results Geochem. 1, 100005 (2020).

22. Beerling, D. J. \& Brentnall, S. J. Numerical evaluation of mechanisms driving Early Jurassic changes in global carbon cycling. Geology 35, 247-250 (2007).

23. Rubesam, W., Mayer, B. \& Schwark, L. Cryosphere carbon dynamics control early Toarcian global warming and sea level evolution. Glob. Planet. Change 172, 440-453 (2019).

24. Pieńkowski, G., Hodbod, M. \& Ullmann, C. V. Fungal decomposition of terrestrial organic matter accelerated Early Jurassic climate warming. Sci. Rep. 6, 31930 (2016).

25. Them, T. R. II et al. High-resolution carbon isotope records of the Toarcian Oceanic Anoxic Event (Early Jurassic) from North America and implications for the global drivers of the Toarcian carbon cycle. Earth Planet. Sci. Lett. 459, 118-126 (2017).

26. Svensen, H. et al. Hydrothermal venting of greenhouse gases triggering Early Jurassic global warming. Earth Planet. Sci. Lett. 256, 554-566 (2007).

27. Aarnes, I., Svensen, H., Polteau, S. \& Planke, S. Contact meatmorphic devolatilizaton of shales in the Karoo Basin, South Africa, and the effects of multiple sill intrusions. Chem. Geol. 281, 181-194 (2011). 
28. Jenkyns, H. C. Geochemistry of oceanic anoxic events. Geochemistry. Geophysics. Geosystems. 11, GC002788 (2010).

29. Aarnes, I., Svensen, H., Connolly, J. A. \& Podladchikov, Y. Y. How contact metamorphism can trigger global climate changes: Modeling gas generation around igneous sills in sedimentary basins. Geochimica et. Cosmochimica Acta 74, 7179-7195 (2010).

30. Iyer, K., Rüpke, L. \& Galerne, C. Y. Modeling fluid flow in sedimentary basins with sill intrusions: Implications for hydrothermal venting and climate change. Geochem., Geophysics, Geosystems 14, 5244-5263 (2013).

31. Galerne, C. Y. \& Hasenclever, J. Distinct degassing pulses during magma invasion in the stratified Karoo Basin - new insights from hydrothermal fluid flow modeling. Geochem. Geophysics. Geosystems. 20, 2955-2984 (2019).

32. Svensen, H. H. et al. Understanding thermogenic degassing in Large Igneous Provinces: Inferences from the geological and statistical characteristics of breccia pipes in the western parts of the Karoo Basin. Geological Society of America Books, Special Paper, 544 (2020).

33. Donnadieu, Y. et al. A mechanism for brief glacial episodes in the Mesozoic greenhouse. Paleoceanogr. Paleoclimatol. 26, PA002100 (2011).

34. Goddéris, Y., Donnadieu, Y., Le Hir, G., Lefebvre, V. \& Nardin, E. The role of palaeogeography in the Phanerozoic history of atmospheric CO2 and climate. Earth-Sci. Rev. 128, 122-138 (2014).

35. Boulila, S. et al. Astronomical calibration of the Toarcian Stage: implications for sequence stratigraphy and duration of the early Toarcian OAE. Earth Planet. Sci. Lett. 386, 98-111 (2014).

36. Caruthers, A. H., Grocke, D. R. \& Smith, P. L. The significance of an Early Jurassic (Toarcian) carbon-isotope excursion in Haida Gwaii (Queen Charlotte Islands), British Columbia, Canada. Earth Planet. Sci. Lett. 307, 19-26 (2011).

37. De Lena, L. F. et al. The driving mechanisms of the carbon cycle perturbations in the late Pliensbachian (Early Jurassic). Sci. Rep. 9, 1-12 (2019).

38. McArthur, J. M., Donovan, T. D., Thirlwall, M. F., Fouke, B. M. \& Mattey, D. Strontium isotope profile of the early Toarcian (Jurassic) oceanic anoxic event, the duration the ammonite biozones, and belemnite palaeotemperatures. Earth Planet. Sci. Lett. 179, 269-285 (2000).

39. Kemp, D. B., Coe, A. L., Cohen, A. S. \& Weedon, G. P. Astronomical forcing and chronology of the early Toarcian (Early Jurassic) oceanic anoxic event in Yorkshire, UK. Paleoceanography 26, 1-17 (2011).

40. Clémence, M. E. et al. Micropalaeontologic, geochemical and cyclostratigraphic approach for the timing of the early Toarcian oceanic anoxic event in the Paris Basin (GPF-Sancerre borehole). Volumnia Jurass. 4, 154-156 (2006).

41. Krencker, F.-N., Bodin, S., Suan, G., Kabiri, L. \& Immenhauser, A. Assessing the duration and possible causes of the earliest Toarcian carbon isotopic excursion. EGU General Assembly Conference Abstracts. 4970 (2013).

42. Suan, G. et al. Duration of the Early Toarcian carbon isotope excursion deduced from spectral analysis: consequence for its possible causes. Earth Planet. Sci. Lett. 267, 666-679 (2008).

43. Suan, G., van de Schootbrugge, B., Adatte, T., Fiebig, J. \& Oschmann, W. Calibrating the magnitude of the Toarcian carbon cycle perturbation. Paleoceanography 30, 495-509 (2015).

44. Stordal, F., Svensen, H. H., Aarnes, A. \& Roscher, M. Global temperature response to century-scale degassing from the Siberian Traps Large igneous province. Palaeogeogr., Palaeoclimatol., Palaeoecol. 471, 96-107 (2017).

45. Pieńkowski, G., Hesselbo, S., Barbacka, M. \& Leng, M. J. Non-marine carbonisotope stratigraphy of the Triassic-Jurassic transition in the Polish Basin and its relationship to organic carbon preservation, $\mathrm{pCO} 2$ and palaeotemperature. Earth-Sci. Rev. 210, 103383 (2020).

46. Jones, M. T., Jerram, D. A., Svensen, H. H. \& Grove, C. The effects of large igneous provinces on the global carbon and sulphur cycles. Palaeogeogr., Palaeoclimatol., Palaeoecol. 441, 4-21 (2016).

47. Svensen, H. H., Polteau, S., Cawthorn, G. \& Planke, S. Sub-volcanic intrusions in the Karoo Basin, South Africa in Physical geology of shallow magmatic systems (eds Breitkreuz, C., \& Rocchi, S.) (Advances in Volcanology, Springer, 2018).

48. Yemane, K., Siegenthaler, C. \& Kelts, K. Lacustrine environment during lower Beaufort (upper Permian) Karoo deposition in Northern Malawi. Palaeogeogr. Palaeoclimatol. Palaeoecol. 70, 165-178 (1989).

49. Faure, K. \& Cole, D. Geochemical evidence for lacustrine microbial blooms in the vast Permian Main Karoo, Paraná, Falkland Islands and Huab basins of southwestern Gondwana. Palaeogeogr. Palaeoclimatol. Palaeoecol. 152, 189-213 (1999).

50. Scheffler, K., Buehmann, D. \& Schwark, L. Analysis of late Palaeozoic glacial to postglacial sedimentary successions in South Africa by geochemical proxies - Response to climate evolution and sedimentary environment. Palaeogeogr. Palaeoclimatol. Palaeoecol. 240, 184-203 (2006).

51. Branch, T., Ritter, O., Weckmann, U., Sachsenhofer, R. F. \& Schilling, F. The Whitehill Formation - a high conductivity marker horizon in the Karoo Basin. South Afr. J. Geol. 110, 465-476 (2007).
52. Svensen, $H$. et al. Nitrogen geochemistry as a tracer of fluid flow in a hydrothermal vent complex in the Karoo Basin, South Africa. Geochimica et. Cosmochimica Acta 72, 4929-4947 (2008).

53. Götz, A. E., Ruckwied, K. \& Wheeler, A. Marine flooding surfaces recorded in Permian black shales and coal deposits of the Main Karoo Basin (South Africa): Implicatipns for basin dynamics and cross-basin correlation. Int. J. Coal Geol. 190, 178-190 (2018).

54. Jones, S. M., Hogget, M., Greene, S. E. \& Dunkley Jones, T. Large Igneous Province thermogenic greenhouse gas flux could have initiated PaleoceneEocene Thermal Maximum climate change. Nat. Commun. 10, 5547 (2019).

55. Heimdal, T. H., Jones, M. T. \& Svensen, H. Thermogenic carbon release from the Central Atlantic magmatic province caused major end-Triassic carbon cycle perturbations. Proc. Natl Acad. Sci. USA 117, 11968-11974 (2020).

56. Goddéris, Y. \& Joachimski, M. M. Global change in the Late Devonian: modelling the Frasnian-Famennian short-term carbon isotope excursions. Palaeogeogr., Palaeoclimatol., Palaeoecol. 202, 309-329 (2004).

57. Jacob, R. Low frequency variability in a simulated atmosphere ocean system. Ph.D. Thesis, University of Wisconsin, Madison, USA (1997).

58. Besse, J. \& Courtillot, V. Apparent and true polar wander and the geometry of the geomagnetic field over the last 200 Myr. J. Geophys. Res.: Solid Earth. 107, EPM 6-1-EPM 6-31 (2002).

59. Freeman, K. H. \& Hayes, J. M. Fractionation of carbon isotopes by phytoplankton and estimates of ancient $\mathrm{CO} 2$ levels. Glob. Biogeochemical Cycles 6, 629-644 (1992).

60. Torsvik, T. H. \& Cocks, L. R. M. Earth history and palaeogeography. (Cambridge University Press, Cambridge, United Kingdom, 2016).

61. Luttinen, A. V. Bilateral geochemical asymmetry in the Karoo large igneous province. Sci. Rep. 8, 5223 (2018).

\section{Acknowledgements}

This work was supported by the Research Council of Norway through its Centers of Excellence funding scheme (project number 223272), which included a field excursion to South Africa and Lesotho in 2018. M.T.J. was funded by the Research Council of Norway with project number 263000 .

\section{Author contributions}

T.H.H. and H.H.S. initiated the project that led to this manuscript. T.H.H. and Y.G. performed the GEOCLIM modelling. M.T.J. created Fig. 1. T.H.H. created the remaining figures and wrote the manuscript, but all authors contributed to discussions of the results and commented on the manuscript.

\section{Competing interests}

The authors declare no competing interests.

\section{Additional information}

Supplementary information The online version contains supplementary material available at https://doi.org/10.1038/s41467-021-26467-6.

Correspondence and requests for materials should be addressed to Thea H. Heimdal.

Peer review information Nature Communications thanks Guillaume Paris and Mariano Remírez for their contribution to the peer review of this work.

Reprints and permission information is available at http://www.nature.com/reprints

Publisher's note Springer Nature remains neutral with regard to jurisdictional claims in published maps and institutional affiliations.

\section{(i)}

Open Access This article is licensed under a Creative Commons Attribution 4.0 International License, which permits use, sharing, adaptation, distribution and reproduction in any medium or format, as long as you give appropriate credit to the original author(s) and the source, provide a link to the Creative Commons license, and indicate if changes were made. The images or other third party material in this article are included in the article's Creative Commons license, unless indicated otherwise in a credit line to the material. If material is not included in the article's Creative Commons license and your intended use is not permitted by statutory regulation or exceeds the permitted use, you will need to obtain permission directly from the copyright holder. To view a copy of this license, visit http://creativecommons.org/ licenses/by/4.0/.

(C) The Author(s) 2021 